\title{
建替団地内の緑地の再整備による居住者の印象及び利用の変化
}

\section{Changes in the Way Residents Perceive and Use Redeveloped Green Belts in Rebuilt Areas}

\author{
小木曽 裕* 根本 和晃** 藤崎健一郎***
}

\author{
Yutaka KOGISO Kazuaki NEMOTO Kenichirou FUJISAKI
}

\begin{abstract}
The aim of this study is to elucidate how residents' perception and use of green belts ("forests") in housing complexes changed when such spaces were redeveloped in order to meet residents' needs to eliminate parts considered as obstacles from the viewpoints of perception and utilization. The opinion of residents about the forest space in Tamadaira was that its balance was improved by the redevelopment, its overall atmosphere was lightened, and the space became easier to use. Consequently, the forest was considered to have become more valuable. The use of forests preserved in the area also increased as a result of redevelopment, and the residents' perception of the forests was improved. This higher evaluation is attributed to the comprehensive improvement of forests in accordance with the needs of residents, whereby the presence of forests was the objective of planning and scholarship through long-term workshops and green academic seminars.
\end{abstract}

Keywords: forest, green tract of land, rebuilding housing complex, impression, visitor, reconstruction キーワード : 森, 緑地, 建替団地, 印象, 利用者, 再整備

\section{1. はじめに}

近年都市の市街地の環境は益々悪化している。環境配慮が叫ば れる今日, 公共の公園や緑は整備から改修や維持管理の時代に入 り，質の向上が重要になってきている。そのような中で，市街地 の民地の緑は，住まい手にとって身近にある緑として効用は大き く, 周辺環境と相まった佇まいや雾囲気を含め人の心を捉えるこ とができ, 日常触れられる貴重な緑であり、多くの価值がある ${ }^{1 ｝ \text { 。 }$

その中でも，計画的に屋外環境を配慮して計画した集合住宅団 地の空間には，纏まった緑地が保全されている団地がある。集合 住宅団地には，同潤会アパートや公営住宅等があるが2)、その中 で昭和30年から継続的に供給している都市再生機構（以下都市機 構)の団地にも, 緾まった緑地が保全されているところがある3）。

しかし，建設後長い年月の中で屋外空間の居住者のニーズや利 用の変化, また樹木の維持管理の対応の難しさから, 居住者の緑 地に対する印象の変化が見受けられ, 緑地空間そのものの利用に も支障をきたす場合がある ${ }^{4 ）}$ 5)。集合住宅の緑の多くは民有地の 緑であり, 公的な緑地を補完する上でも, 前述のように都市の中 でこの緑は貴重な緑地空間であり，持続的に維持されることが望 まれるところである ${ }^{6)}$

集合住宅団地の緑地や樹木に関する研究については, ニュータ ウン内の集合住宅地の樹木の篠沢らの研究 ${ }^{7)}$ があり, 団地に現存 する樹木は生長する変化の過程を通じて, 開発の経緯や履歴を反 映した特徵を有していることを明らかにしている。建替えに伴う 集合住宅団地の緑地の変化の事例調査を通じて，事業主体や住宅 の所有関係別の量的及び機能的変化の実態を明確化した田中らの 研究8) がある。また、公団住宅の外部空間の構成を定量的に把握 した基礎的研究9) では, 大規模開発時代の公団住宅の環境に注目 が集まりがちであるが，量的な面において，近年整備された外部 空間も都市内における重要な環境資源として機能し得るとしてい
る。武田 ${ }^{10)}$ は，居住者の利用実態から今後の外部空間の整備 方針を検討し，外部空間が集合住宅団地の居住空間として不可欠 な要素としている。一方，既存樹木を計画的に有効に活用した建 替団地の緑について，居住者の高い評価を得ていることがわかつ

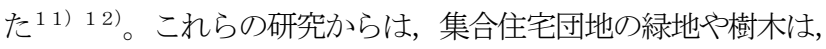
それぞれの開発や計画の経緯から保存されたり生長し, 量的, 質 的にも，また利用においても意識の面からも，居住者から高く評 価がされていることが示されている。

これらの研究を踏まえ, 本研究では, 集合住宅団地において, 都市環境として価值が高いと思われる歴史のある纒まった緑地に 焦点を当てることとした。集合住宅団地に従前からある纏まった 緑地を，建替事業に伴い利用者の印象や利用の観点から支障の部 分を取除き, 計画的にニーズに即して再整備することにより，居 住者の印象や利用がどのように変化したかを明らかにすることを 目的とした。

\section{2. 研究の方法}

\section{(1) 研究対象地の概要}

本研究の対象地は, 研究の目的を達成する為に都市機構の建替 団地の中から ${ }^{13)}$, 約1haの緑地を有する多摩平団地を選定した。 当団地の緑地は日野台地の桑畑の一画であったが，大正11年に宮 内省帝室林野管理局林業試験場「日野苗圃 (御料林)」が設立され た。昭和 22 年には林政統合により御料林と国有林を統合し林野庁 林業試験場一と改組された。林業試験場時代に植栽されたモミ， ユリノキその他の樹木により緑地を形成している。昭和 23 年には この土地がカナダ教会のストーン牧師の目にとまり中央農村教化 研究所（後の農村伝道学校）が開設された。昭和31年から区画整 理が始まり，昭和33年に日本住宅公団によって多摩平讨地の建設 として入居が始まった。敷地の一画は団地建設後も多摩平団地自

*独立行政法人都市再生機構, **(株今泉造園土木, $* * *$ 日本大学生物資源科学部 
然公園との名称で残され，団地居住者は元より近隣住民にとって も貴重な緑地空間となっている。しかし長い年月の間に樹木が生 長し, 薄暗く入りづらい空間にもなっていた。平成 9 年から団地 建替事業が行われ，第二期の建替に合わせて緑地の再整備が行わ れ，団地名称が「多摩平の森」となったこともあり，自然公園も 同様の「多摩平の森」と呼ばれることになった ${ }^{11)}$ 。現在の団地は 敷地面積が約10.3ha，3箇所の街区で構成され，第一期383戸，第 二期562戸，第三期 583 戸の計 1,528 戸からなる ${ }^{14)}$ 。

\section{(2) 多摩平の森の学際研究と居住者との合意形成}

建替事業の中で歴史ある森をどのように保存・利活用していく かの再生計画を立案するために, 建替事業の着手前の平成8年度 より，委員会形式の「既存樹林の保存・利活用に関する調査」の 学術的研究を行った。3年間検討の結果, 森の保存・利活用の次 の3つの基本方針と森の利活用概念図を作成した。1）既存樹林 を次世代に引き継ぐ，2）自然との共生を図りながら既存樹林を 育てる，3）自然システムを活かした管理を行う。また，居住者 との緑のワークショップは, 事業者と居住者の代表とコンサルタ ントが連携し事務局となり, 打ち合わせや見学等も実施し, 事業 着手後の平成10年度から16年度までの間, 従前居住者の自由参加 で24回が実施された。その中の約7割が森の再生に関わるもので ある。平成10年度は, 「森の現況の把握, 森の継承・育成の基本 的な方向性 (マスタープランの作成)」, 平成 12 年度は「森の土壤・ 樹木の現況, 居住者の参加の検討」を, 平成13年度は「森の野鳥 観察会, 自然観察会等の実施」, 平成 $14 \cdot 15$ 年度には「森と水辺 の事例見学を踏まえた提案」を，平成16年度には「実施設計一の 提案と現場確認, 森の居住者の管理分担検討」を行っている。毎 回 30 人から 50 人近くの人の参加で実施され，その結果は，毎回， 事務局でまとめて全居住者にニュースで報告している ${ }^{14)}$ 。これら の二つの取り組みにより, 建替事業のテーマである「緑の継承と 育成」を基に森の再整備によって, 薄暗い雾囲気や歩きにくさ等, 森の利用上での諸問題の解決を図るとともに, 森の貴重な既存樹 木や林床を保全し樹林の自然性を高めた。また, 団地居住者は元 より周辺住民の利用も図り, 大きく北側から「雑木林ゾーン」,「力 ツラ林ゾーン」,「モミ林ゾーン」,「アカマツ林ゾーン」を中心に 自然観察や自然とのふれあいの場, 休息の場等に活用していくと いった環境づくりの拠点を創出した（図-1・5)。

\section{（3）調査方法}

調査方法は, 現地踏査で団地と緑地の関係と緑地の状態を確認 した上で，アンケート案を作成し、都市機構（管理

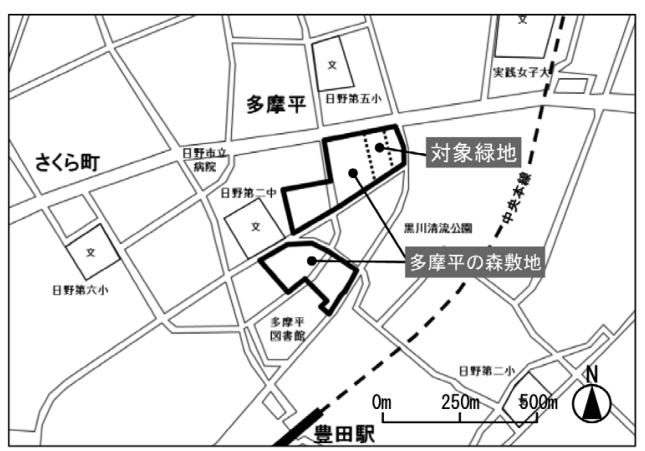

図 - 1 多摩平の森調査対象地位置図

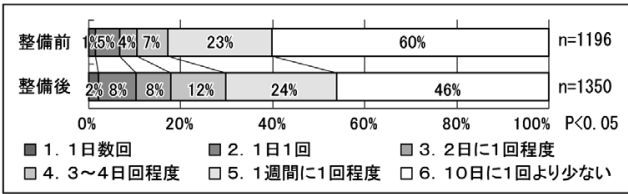

図 -2 森の再整備前後の利用の変化
部門）及び団地自治会へヒアリングを行った。その結果を考慮し アンケート票を作成し，内容について居住者に説明会を行った。 平成22年6月に空家等を除く 1,495 戸に対し，アンケート票を配布 した。ここからは緑地としての多摩平の森は「森」に，団地名称 は「多摩平の森」と記載する。アンケート内容は森に対する「利 用内容・良し悪し・歴史の認知・緑の量等」で結果を集計し，「森 の整備前と整備後の利用方法の変化」について，また「森の印象 については整備前と整備後の印象の変化を 13 項目の形容詞対に ついて5段階の尺度」での確認を行い，統計処理を実施した。合 わせて, 現地調査を平成 22 年 4 月から翌 1 月までの毎月 1 回, 定点 で写真を撮影し，2ヶ月毎に1回（計5回 : 平日2回・日曜 2 回・土 曜1回， 6 時〜 18 時間), 利用者の人数・利用内容を調査した。

\section{3. 解析結果 · 考察}

\section{（1） 属性等}

アンケートの回収数は 416 戸で回収率は $36.7 \%$ であり, 回答者 の性別は，男性 $37.7 \%$ ，女性 $62.3 \%$ で，年齢構成は 60 歳以上が $83 \%$ と高齢者の比率が多かった。本団地では戻り入居が $78.2 \%$ を 占めており，建替以前からの居住者が多いため，新規団地に比べ て高齢者が多かったと考えられる。家族構成は，先に 60 歳以上 の居住者が多いと記したが，特に一人暮らしの $90.6 \%$ ，二人暮ら しの 86.9\%が 60 歳以上であった。回答者は子育てを終えた世代 の割合が多いと考えられる。

\section{（2）森の利用と管理}

森の居住者の利用についてt検定を行った。その結果、 $(\mathrm{P}<$ 0.05）で再整備前よりも再整備後の方が利用頻度が高いことがわ かった（図－2）。

森の利用内容は「散歩したり, ベンチでくつろいだりする」と 「通りすがりに眺める」が最も多く，概ね同等の3割で，眺める だけの人の割合が多い傾向であった。また，居住者は森を「植物 や昆虫の観察」としての利用する人が約1割で，「子供を遊ばせた り運動させる」，「友人との談話の場」とする人が概ね $25 \%$ で，一 部「通勤通学の場」としての機能も有寸ることもわった（図－3）。 また，現地での利用実態調査から，一日の平均利用者は通過人数 を入れると 365 人で通過を除くと 68 人であり, その中で散歩が約 2 割，ランニング，観察，体操と続く。一方，住まいの身近に森が あることについての善し悪しについて，「良い」とする人は約9割 と多く（図-3)，住まいに近接して1haの森があり，日常生活の

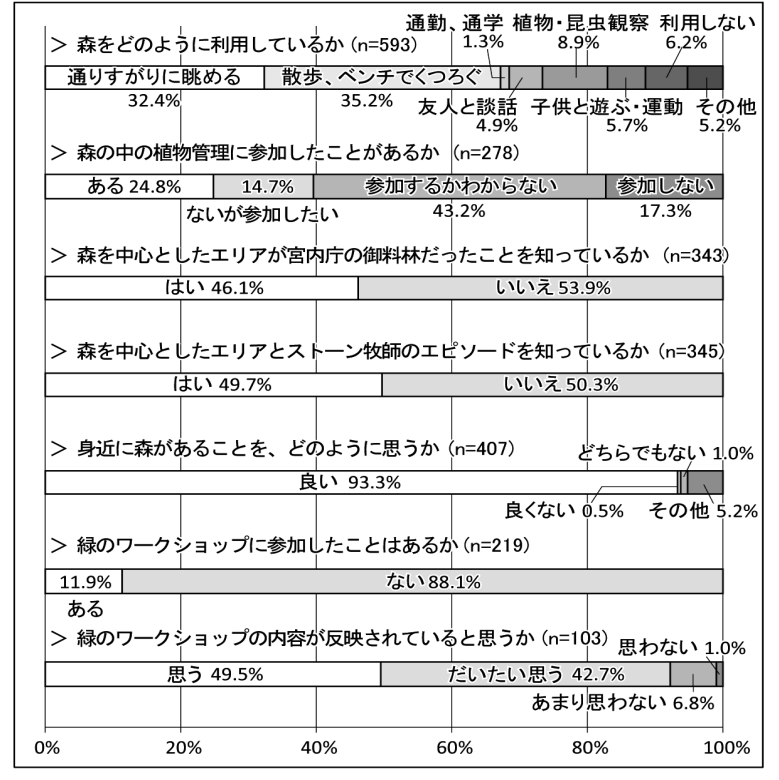

図 - 3 森に係る居住者評価
中で自然に触れること に価值を感じている。 この傾向は, 団地の住 まいの身近にビオトー プが設置されているこ とが高い評価を得てい る傾向に似ていて ${ }^{15)}$, 再整備されたこの森に ついて，活動的な場だ けでなく，通りすがり にさりげなく眺めるだ けでも価值があること を示している。

一方, 森の維持管理 に関しては，定期的に 居住者の有志による下 草刚りや共同花壇の管 理が行われており，こ の活動を知る人は $75.1 \%$ ，その内「参加 
したことがある」は $24.8 \%$, 「参加したことはないが今後参加して みたい」が14.7\%となった。「参加したことはなく, 今後も参加す るかわからないが $43.2 \%$ と最も多かったが, 前述より多摩平の 森は高齢者が多い為, 体力的な面で判断し難いと思われる。しか し7割以上の人が居住者による管理について知っていることから， 管理については関心があると思われる（図－3）。

\section{（3）森の歴史の認知と感じ方}

森の歴史に関する質問については団地居住者の概ね半数が「知 っている」と回答しており，ストーン牧師が洞爺丸の台風による 海難事故の際に青年を助けて自らの命を落とした史実などが，緑 のワークショップや森に設置されている案内板などによって人々 に知られるようになったことで，この森に対する思い入れが大き くなったと思われる。

身近に森があることに関する感じ方については $90 \%$ 以上が「良 いと思う」と回答している。緑のワークショップの参加者はワー クショップ認知者の約 1 割であったが, 緑のワークショップで取 りまとめた内容が, 現在の森に反映しているかについては, 「思う」, 「だいたい思う」合わせて，9割以上の人が回答している。

\section{(4) 森の印象の変化}

1) 森の再整備前後の印象の変化

森の印象や感じ方に関する形容詞対の 13 項目を5段階で全体に 確認し，整備前後の印象の差を $\mathrm{t}$ 検定で確認した。

その結果「暗い,「落葉が迷惑」「危ない,「気味が悪い」の 否定的な形容詞対は $(\mathrm{P}<0.01)$ で大きく改善され評価がされてお り,より安全・快適に森を利用できるようになったことが伺える。 また, 肯定的な形容詞対の「安らぎを感じる」,「愛着がある」,「の びのびしている」、「美しい」は（P<0.01） と評価は高く，「季節 感がある」も（P<0.05）と評価は上昇していて，「うっとうしい

$(\mathrm{P}<0.1) 」$ は僅かながら改善されて改修の効果が表れている。一 方, 「歴史性」,「神秘性」,「雄大さ」の評価の差は生じなかった (図 $-4)$ 。

また, 緑のワークショップは従前居住者のみの参加であるが,
その参加の有無で, 居住者の森の整備前後の印象の差を $\mathrm{t}$ 検定で 確認した。その結果, 緑のワークショップに参加者して本アンケ 一トに回答した人は平均年齢は約70歳の 22 名であったが, 統計上 の印象の変化が確認された。それは，「暗い」の（P<0.01）であ り，明るくなった印象を強く評価がされた。「美しい $(\mathrm{P}<0.05) 」$

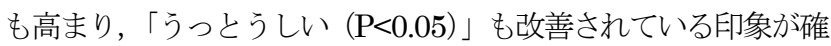
認できた。ただし，緑のワークショップに参加していない従前居 住者はワークショップ参加者が評価していない5項目「のびのび している・気味が悪い・愛着がある・安らぎを感じる・落ち葉が 迷惑・季節感がある」についても $(\mathrm{P}<0.01)$ で改善の評価をして いることが分かった。緑のワークショップには，スタート時から 終了時まで参加していた居住者も多く, 回を重ねる度に, 緑の計 画等に対する知見が高まったとの評価が聞かれている ${ }^{16)}$ 。これら の事により，ワークショップ参加者の方が改善に関する評価をよ り厳しくみていることが示唆された（図 - 4)。

森は，既存樹木を極力保存しながら視界を広げることにより， 地上部に射す光により森を明るく安全にすると共に, 森の在るべ き姿を兼ね備えながら総合的により良くするために一部の樹木を 間引きを行い，再整備を行っている。その結果，再整備の評価は 全体的には高く，再整備前の森の姿を知る人達にとっても，神秘 性や歴史性も評価も持続され，全体的に，団地内の森の再整備は 居住者ニーズに即する整備ができたと考えられる。

2）森の中の気に入った場所

現在の森の印象で「気に入った場所」を示してもらうと共に その理由を記載してもらった。その結果，評価の高い場所は， 森の中央部にある「モミ林ゾーン」で，動線に関係する地点を 評価している。その中でも木デッキや園路は通過だけでなく， 四季の移ろいや歩いた時に足に感じる感触等, 様々な特徵を感 じられるような場所として選択されている。また，休憩や遊び といった滞在型の特徴の地点として木デッキを選択した人が多 く, 以前のモミ林が再整備によって新しい体験型の地点となり, 訪れた人に行ってみたいと思わせるような工夫ができていると

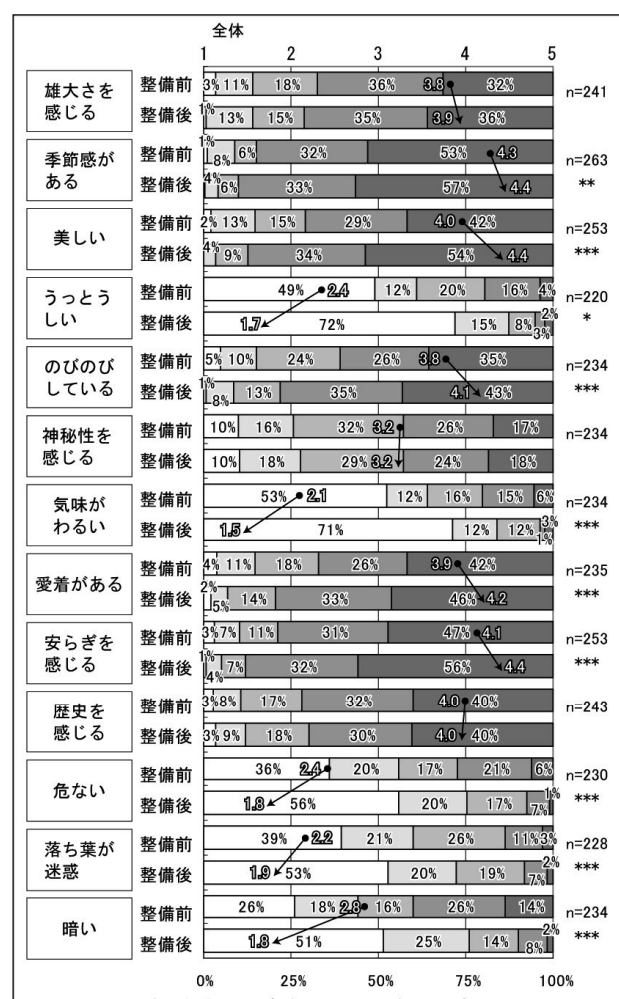

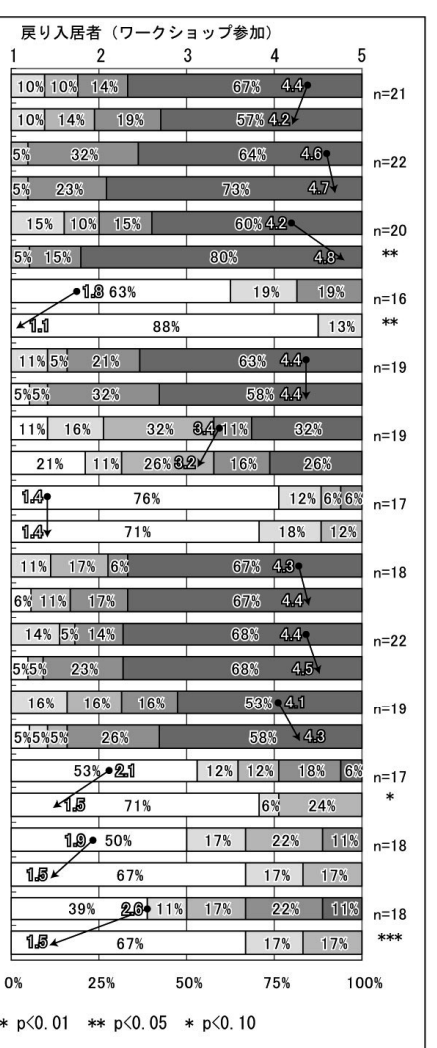

考えられる。評価の 内容も「落ち着いた 感じ・安心感・清凉 感・植物の様々な表 情」が多く，モミ林 の存在と相まって 「山の中にいるよう で野鳥の観察も楽し い(50代・女性)。」, 「デッキが尾瀬の木 道を歩いているよう で気分が良い(50 代・男性)。」など自 らが体験したものが 多いことがわかった。

次に評価されてい るところは,「カラマ ツ林ゾーン」と「雑 木林ゾーン」であり, 「カラマツ林ゾー ン」では，林の間に ある石のあるプレイ ゾーンの評価が高い。

「雑木林ゾーン」ン は，元々ヒノキが林 立し暗いところが， 
明るく開放的な雑木林になり，その間を通るバス停への通り抜け 園路の評価が高かった。その他にも多くの評価があり，「自然的・ 緑の豊かさ・非日常的な避暑地の感じ・楽しく利用・開放感など が挙げられていた（図 $-5 \cdot 6$ )。

\section{4. まとめ}

多摩平の「森」における空間に対する居住者意識は，再整備に よって樹木のバランスが改善され，森全体の䨌囲気が明るくなり 利用しやすくなったことにより，居住空間における森の価值が高 まったのではないかと考えられる。団地に保全された森は再整備 により利用が高まり，印象も改善された。これは長年の緑のワー クショップをはじめ, 緑の学術的な研究会の実施により, 計画的・ 学術的に森の在るべき姿を目指し, 居住者ニーズに即した森の改 善を総合的に行った結果がこのような評価に繋がったと考えられ る。

都市機構では昭和61年から建替事業が実施され，それぞれの団 地で屋外環境や既存の緑の継承に関寸る話し合いがもたれたが, 環境配慮の社会背景や居住者の緑の保全に対する意識が高まる中，

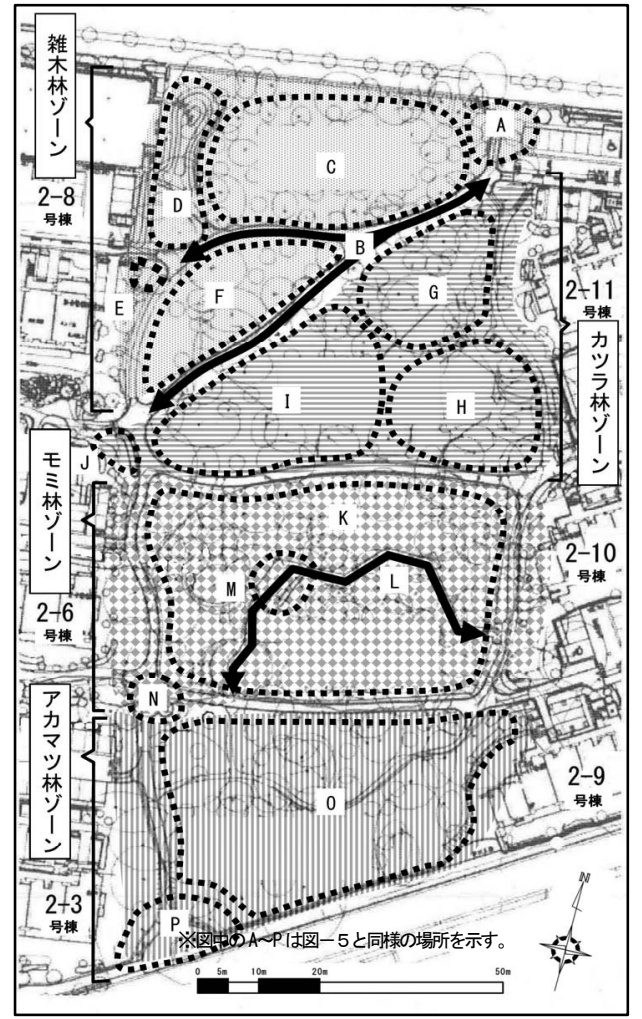

図 - 5 森のゾーニングと気にいっている場所

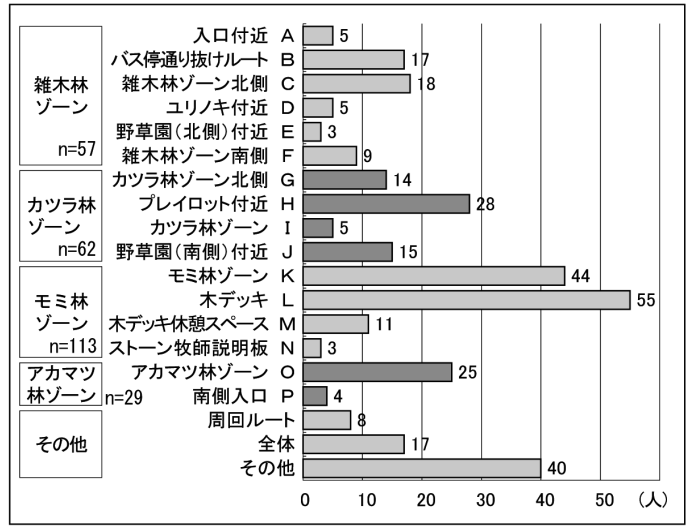

図 - 6 森の印象で気にいっている場所
多摩平団地の 1 haの森は，他に類を見ない大きさと歴史があり， 長年の管理上の課題が多く多面的な検討が必要であった。多摩平 で実施された緑のワークショップは都市機構の建替事業で最初の 試みであり，実施期間は他に類を見ない期間が長く，学術的研究 会等も実施したことが特徴である。その後, 多摩平団地の緑のワ 一クショップ等による緑の合意形成の評価は高く，これを受けそ の後の都市機構の建替事業着手の数団地の合意形成手法に波及を もたらし多大な影響を与えている ${ }^{14)}$ 。

近年の都市再生や団地再生において, 緑地の保全や再生は地域 環境の改善に大いに役立つと考えるが，本研究では団地内の居住 者の利用や意識から，建替団地内の緑地の再整備による居住者の 印象及び利用の変化を把握することができた。今後の団地の再整 備や維持管理の知見を得ることができ，良好な緑地環境を創出す る為の基礎的資料を得ることができた。

最後に，今後の緑の合意形成や計画・設計に関する留意事項を 記載する。緑の調査・計画・設計・管理等における合意形成等に 関して，多くの技術者が一つの方向を向き，居住者，コンサルタ ント, 事業者, 行政, 学際等の本質的で継続的な連携が必要であ る。また，学際の客観的知見と評価，事業着手前の当該エリアを 含めた広域的で総合的な調查・計画の立案が不可欠であり，それ ぞれのプロジェクトにあった、合意形成手法を立案するとともに, 綿密な計画設計も重要と考える。今後, 緑地整備を行う場合には, 計画当初から緑のあるべき姿の本質を理解した上で, 継続し計画 設計施工等を進めることが肝要と考える。その為にも，今後は地 域住民の森に対する利用や意識を明らかにし，より良い緑環境の 為に研究を継続したい。

謝辞

本研究を行う上で, 多摩平の森自治会長笹原武志，事務局長関泉子両氏と自治会の 方々，日本大学の勝野武彦教授，UR 都市機構の鎌田修氏をはじめ職員の方々に指導 とご協力をいただき深く感謝するとともに, アンケート調查をさせていただいた団 地の居住者の方々にこの場を借りて御礼申し上げる。

\section{補注・引用文献}

1）小木兽裕・木村郁美（2010）: 特集・市街地における民地の緑の価值と効用 : ラン ドスケープ研究，73(4)，259.

2）日本造園学会 (1978) : 造園ハンドブック，pp1350 : 技法堂出版，東京.

3）小木曽裕（2003）郊外団地の再生における緑の役割と変遷 : ランドスケープ研究, $66(4), 276 \sim 281$

4）福成敬三（2001）: 造園工事の建設システムにおける成長する樹木の扱いに関する 考察 : 造園技術報告集 (1)，22２5

5）島一喜・澤田正樹・武田重昭・村岡賢二・高橋敦（2009）：集合住宅団地における 植物管理のあり方について : 造園技術報告集（5），28～31

6）小木兽裕 (2010) : 団地建替の緑地整犕からみた公園ストックの評価と継承 : 公園 緑地, 71 (3), 7〜9

7）篠沢健太・宮城俊作・根本哲也・左岦晋吾 (2011)：千里ニュータウン集合住宅に 現存寸る樹木の樹形と立地との関連 : ランドスケーブ研究 74 (5) 749〜752

8）田中陽大・加我宏之・下村泰彦・増田昇（2012）：千里ニュータウンにおける集合 住宅団地の建替えによる緑地構造の変化に関する研究: ランドスケープ研究 $75(5)$ $503 \sim 506$

9）矢込祐太・菅野博貢（2011）：環境資源としての活用を目的と寸る公団住宅外部空 間の定量的実態把握 : ランドスケープ研究, 74 (5)，663〜666

10）武田重明・増田昇・永井心平・小木兽裕・村岡政子 (2010): 利用実態から捉えた 団地屋外空間の利用による団地再生に関寸る研究: ランドスケープ研究 73 (5), 469 $\sim 472$

11）小木曽裕 (2007) : 建替団地における居住者参加による緑地整犕の推倠に関する研 究: 日本大学造園緑地学 No. 5, 134 144

12）小木曾裕 (2011)：既存樹木活用を行った建替団地における住まいから見える緑に 対する居住者意識: ランドスケープ研究, 74 (5)，547〜550

13）都市基般整備公甩（2000）：街とみどりの歩み（网地造園45 年史），235pp.

14）住宅・都市整備公団東京支社（1998）：街と時と人を緑で結ぶ「緑の継承と育成」 その考え方ととりくみ: 多摩平扵地建替事業, $19 \mathrm{pp}$

15）小木曽裕 (2009) : 環境共生型住宅レーベンスガルテン山崎のビオ・ガーデンに対 する居住者意識 : ランドスケーブ研究，72（5)，561〜564

16） 2012 年 11 月に多摩平の森自治会の緑のワークショップ事務局であった居住者に 緑のワークショップへの参加とその評価についてのヒアリングを実施した。

17）小木曽裕（2011）: 団地建替事業の緑に対寸る居住者との合意形成手法の変遷と波 及に関する研究: 土木学会関東支部, IV-15 